\title{
Ortaokul Matematik Öğretmenlerinin Modellemeye İlişkin Hata Yaklaşımlarının İncelenmesi
}

\section{The Investigation of The Middle-School Mathematics Teachers' Error Approaches on Modelling}

\author{
Sibel Bilgili, ${ }^{a}$ Merve Özkaya, ${ }^{\mathrm{b}}$ Alper Çiltaş, ${ }^{\mathrm{c}, *}$ Alper Cihan Konyalıŏlu ${ }^{\mathrm{d}}$ \\ a Araş. Gör. Atatürk Üniversitesi, Kazım Karabekir Eğitim Fakültesi, Matematik ve Fen Bilimleri Eğitimi Bölümü, Erzurum/Türkiye \\ ORCID: 0000-0003-3611-0482

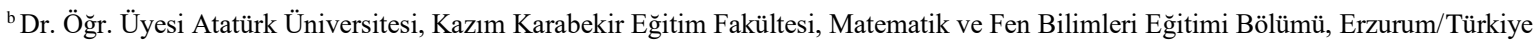 \\ ORCID: 0000-0002-0436-4931 \\ ${ }^{\mathrm{c}}$ Prof. Dr. Atatürk Üniversitesi, Kazım Karabekir Eğitim Fakültesi, Matematik ve Fen Bilimleri Eğitimi Bölümü, Erzurum/Türkiye \\ ORCID: 0000-0003-1024-5055

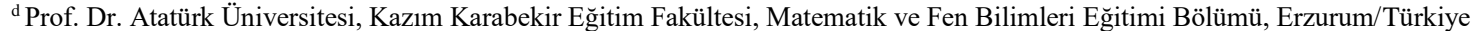 \\ ORCID: 0000-0002-6009-4251
}

\begin{tabular}{l} 
MAKALE BİLGİSİ \\
\hline Makale Geçmişi: \\
Başvuru tarihi: 23 Ekim 2019 \\
Düzeltme tarihi: 16 Şubat 2020 \\
Kabul tarihi: 05 Mart 2020 \\
\hline Anahtar Kelimeler: \\
Hata \\
Hata Temelli Yaklaşım \\
Modelleme \\
Matematik Öğretmeni
\end{tabular}

\section{ARTICLE INFO}

\section{Article history:}

Received 23 October 2019

Received in revised form 16 February 2020

Accepted 05 March 2020

Keywords:
Error
Error Based Approach
Modelling
Mathematics Teacher

ÖZ

$\mathrm{Bu}$ çalışmanın amacı ortaokul matematik öğretmenlerinin çeşitli modeller üzerinde yapılması muhtemel olan hataları belirleyebilme ve bu hataları anlamlı bir şekilde açıklayabilme durumlarını incelemektir. Durum çalışması yönteminin benimsendiği bu çalışma 10 ortaokul matematik öğretmeniyle yürütülmüştür. Veriler yedi soru içeren bilgi testiyle toplanmıştır. Bu testteki her bir soru için doğru ya da hatalı iki çözüm yapılmıştır. Yapılan değerlendirilmelerde anlaşılmayan noktaları ortaya koyabilmek için her bir öğretmenle görüşmeler yapılmıştır. Elde edilen verilerin analizinde içerik analizi kullanılmıştır. Yapılan içerik analizi doğrudan alıntılarla desteklenmiştir. Çalışma sonunda öğretmenlerin çoğunun gerçekleştirilen çözümü değerlendirirken doğru-hatalı çözümü ayırt etmede zorlandıkları tespit edilmiştir.

\section{A B S T R A C T}

The purpose of the study was to investigate the middle-school mathematics teachers' states of identification of possible error in various models and explanation of these error in a meaningful way. The study that employs the case study method was conducted with 10 middle-school mathematics teachers. Data was collected by the knowledge test including seven questions. The solutions that were prepared by using different models were presented to them as two different solution papers and see interviews. Content analysis was used in the analysis of the obtained data and it was supported by the direct quotations. At the end of the study, it was determined that most of the teachers struggled with the distinction of the correct or wrong solution when evaluating the presented solutions.

\section{Giriş}

Lesh ve Doerr'a (2003) göre model, karmaşık sistemleri ve yapıları yorumlamak ve anlamak için zihinde var olan kavramsal yapılar ile bunların dış gösterimlerinin tamamıdır. Matematiksel model ise, belli bir amaç için oluşturulmuş ve gerçeğin bir parçasıyla ilişkili olan soyut, basitleştirilmiş bir yapıdır (Akgün, Çiltaş, Deniz, Çiftçi ve Işık, 2013). Başka bir ifade ile matematiksel semboller,

*Sorumlu yazar/Corresponding author. e-posta: alperciltas@atauni.edu.tr 
kavramlar ve ilişkiler kullanılarak günlük durumları ifade etmeye yarayan modellerdir (Stickles, 2006). Modelin basit anlamda hiç alışık olunmayan bir sistem ile önceden bilinen sistemler arasında bağ kuran bir analoji olduğunu ifade eden Lehrer ve Schauble (2003), bunun ön öğrenmeleri de kapsamasından dolayı anlamlandırmada da kolaylık sağladığını belirtmektedir. Eğitimde kullanılan modellerle öğrencilerin zihinsel süreçlerinin ve ürünlerinin açığa çıkarılıp zenginleştirilmesi (Eisner, 1997) ve kavramlar arası ilişkilerin ortaya konulup kavramsal öğrenmenin desteklenmesi (Ulusal Matematik Öğretmenleri Konseyi [NCTM], 2000) sağlanmaktadır.

Matematik problemlerinin çözümünde basit geometri, cebir ve sayı ile ilgili modelleri kullanmanın önemli olduğunu ifade eden Lesh, Landau ve Hamilton (1983) bu sayede matematiğin günlük yaşamda anlamlı olacağını belirtmektedir. Arzarello, Ferrara ve Robutti (2012) ise günlük yaşam problemlerinin çözümünde grafiksel, sayısal, cebirsel ve sembolik modellerle karşılaşıldığını; Brenner ve arkadaşları (1997) ise sözel ifadeler, grafikler, tablo ve denklemler gibi modelleri oluşturmayı ve oluşturulan modelleri çözüm sürecinde kullanmanın önemli olduğunu vurgulamaktadirlar. Ayrıca Tversky (2001) modellerin; dikkat çekmek, bilgileri kaydetmek ve hafizayı desteklemek, iletişim kurmak, çıkarımda bulunmaya ve keşfetmeye yardımcı olmak için kullanılabileceğini ifade etmektedir. Matematiksel modeller, gerçek hayatta var olan bir durumun fiziksel özelliklerini tanımlamaktan ziyade durumun yapısal ve işlevsel özelliklerini açıklamaya odaklanırlar ve gerçek hayatta var olan karmaşık yapıları, fikirleri, kavramları, teoremleri açıklarlar (Çavuş-Erdem ve Gürbüz, 2018). Dolayısıyla matematiksel modeller, bir matematiksel kavramın, teoremin, kuralın veya ilişkinin doğru algılamasını ve içselleştirilmesini kolaylaştırmayı hedefleyen zihinsel bir resim olarak düşünülebilir. Bir başka ifade ile matematiği anlamayı sağlayan görselleştirmelerdir.

Model oluşturmadaki temel amaç, modeller yardımı ile bir duruma veya olaya açıklı getirebilmektir. Yani matematiksel modeller, bir gerçek yaşam probleminin çözümünden basit bir eşitliğin anlaşılmasına kadar birçok durumda çözüme ulaşmayı sağlayan, iki veya daha fazla değişken arasındaki ilişkinin açıklandığı matematiksel gösterimlerdir. Bu gösterimleri Meyer (1984) değişken, sabit, fonksiyon, eşitlik, eşitsizlik, formül, grafik, sembol, tablo, resim, diyagram gibi matematiksel kavram parçaları olarak belirtmiştir. Yani bir matematiksel model bir ifadenin, olayın veya olgunun anlaşılmasında kullandığımız matematiksel araçlardır.

Matematiksel araç olarak da ifade edilen matematiksel modeller, matematiksel kavramların somutlaştırılmasında ve buna bağlı olarak bu kavramların zihinde doğru bir şekilde yer etmesinde önemli bir etkendir. Matematiksel kavramlar matematiksel bilginin en küçük yapı taşıdır (Çiltaş, 2011). Eğer bireyde matematiksel öğrenme istenilen düzeyde gerçekleşmişse, kavramların zihinde şekillenmesi sonucunda kavramsal öğrenme gerçekleşir. Diğer bir ifade ile kavramsal öğrenmenin öğrenciler tarafından gerçekleştirilmesi için kavramların yüzeysel olarak değil, anlamının derinleştirilerek öğrenilmesi gerekmektedir. Bu gereklilik göz önüne alındığında bilinen bir bilginin tekrarı yeterli olmayacaktır. Çünkü bilinen bilginin tekrarı farklı bakış açıları kazanmayı güçleştirmektedir. Farklı bakış açıları kazandırmak ve hatta sorgulama becerisini geliştirmek için ise negatif bilgiye ihtiyaç vardır (Akpınar ve Akdoğan, 2010).

Parviainen ve Eriksson (2006) yaptıkları çalışmada negatif bilgi ve pozitif bilgiyi karşılaştırmışlardır. İnançlarla şekillenen doğru bilgiyi pozitif bilgi; öğrenilmeden geri plana atılmış bilgiyi ise negatif bilgi olarak açıklamışlardır. Bir bireyin ne yapmaması gerektiğini ya da ne bilmediğini bilmesini ise pozitif ve negatif bilginin bir arada kullanılmasıyla ortaya çıktığını vurgulamışlardır. Parviainen ve Eriksson (2006)'dan farklı olarak bazı çalışmalarda bireyin ne bilmediğini bilmesi, kaçınılması gerekenleri bilmesi sadece negatif bilgi olarak açıklanmıştır (Gartmeier, Bauer, Gruber, \& Heid, 2008; Tauber, 2009'dan akt. Akpınar ve Akdoğan, 2010). Bickhard'a (2004) göre ise negatif bilgi öğrenmede hatayı kullanabilmektir (Akt. Akpınar ve Akdoğan, 2010).

Herhangi bir kavrama yönelik hataları ortaya koymaya yönelik çalışmalar vardır (Radatz, 1979). Bu çalışmalardan farklı olarak Borasi (1988), hataları öğrenmenin sağlanmasında bir sıçrama tahtası olarak nitelendirmiştir. Ayrıca hataların ya ortaya konduğunu ya da yapılmaması gerekenler şeklinde kullanıldığını belirtmiştir. Bunların aksine Borasi (1986; 1988; 1989; 1996), Gedik (2014; 2019), Özkaya (2015), Konyalıŏlu, Özkaya ve Gedik, 2019) ve Akkuşci (2019) hataları öğrenme sürecine katmıştır. Bu çalışmalara göre matematik alanı için hatalar, öğrencilere neyin doğru neyin yanlış olduğunu fark ettirmiştir ve öğrenciler uzmanlar tarafından profesyonelce hazırlanan hatalarla farklı bakış açıları kazanmışlardır. Ayrıca hata içerikli çözümler öğrencileri araştırmaya yöneltmiş ve bu şekilde sorgulama becerileri geliştirilmiştir. Yapılandırmacı yaklaşımın benimsenmesiyle birlikte hata, kaçınılması gereken olmak yerine bir öğretim aktivitesi olarak kullanılmaya başlanmıştır (Borasi, 1996).

Öğretimde hataların kullanılmasıyla beraber bir şeyin neden doğru olduğunun yanı sıra neden yanlış olduğunun da açıklanması önemli bir hal almıştır. Matematiğin çeşitli konularında öğrencilerin veya öğretmenlerin profesyonel hataları belirleyebilme durumlarına yönelik çalışmalar mevcuttur (Borasi, 1986; 1989; 1994; Demirci, Özkaya ve Konyalığlu, 2017; Gedik, 2014; Özkaya, 2015, Özkaya ve Konyalıŏ̆lu, 2019).

Matematiksel modellemenin son yıllardaki yükselişi yadsınamaz bir durumdur. Yapılan çalışmalar matematiksel modellemenin, matematiksel düşünme (English, \& Watters, 2004) ve üst düzey düşünme (Lingefjard, 2005) becerisini geliştirdiğini göstermiştir. Matematiksel modellemenin bir yöntem olarak kullanıldığı çalışmalarda bu yöntemin başarıyı etkilediği görülmüştür (Çiltaş, 2011; Sağırlı, 2010). Ayrıca matematiksel modellerin öğretim sürecine entegrasyonunu sağlayacak olan öğretmenlerin matematiksel modelleme hakkında yeterli bilgiye sahip olmaları gerekmektedir. Matematiksel modelleme hakkında yeterli olmayan öğretmenlerin matematiksel modelleri, anlamayı kolaylaştıran görseller olarak düşündükleri ortaya konmuştur (Akgün, Çiltaş, Deniz, Çiftçi ve Işık, 2013). Öğretmenlerin matematiksel model oluşturmalarının yanı sira oluşturulan bir matematiksel modeli yorumlayabilmelerinin değerlendirebilmelerinin gerektiğ düşünülmektedir. $\mathrm{Bu}$ doğrultuda araştırma problemi “ortaokul matematik öğretmenlerinin çeşitli modeller 
üzerinde yapılması muhtemel olan hataları belirleyebilme ve bu hataları anlamlı bir şekilde açıklayabilme durumları nasıldır?” şeklinde belirlenmiştir.

Araştırma, uygulama açısından modelde yer alması olası hatalarla hazırlanan bilgi testiyle, 10 matematik öğretmeninin hazırlanan bilgi testine verdikleri yazılı ve sözlü cevaplarla ve uygulamaya katılan öğretmenlerin bilgileri, deneyimleri, yaklaşımları, görüşleri ve araştırmacıların deneyimleri ile sınırlı kalmaktadır.

\section{Yöntem}

Bu bölümde araştırmanın deseninden, çalışma grubundan, veri toplama aracindan, verilerin toplanmasından, verilerin analizinden, çalışmanın inanılırlığından ve tutarlılığından bahsedilmektedir.

\subsection{Araştırmanın Deseni}

$\mathrm{Bu}$ çalışmada ortaokul matematik öğretmenlerinin çeşitli modeller üzerinde yapılması muhtemel olan hataları belirleyebilme ve bu hataları anlamlı bir şekilde açıklayabilme durumları incelenmiştir. $\mathrm{Bu}$ amaç doğrultusunda çalışmada nitel yaklaşım yöntemlerinden biri olan durum çalışması yöntemi kullanılmıştır. Nitel yaklaşımın kullanıldığı çalışmalarda araştırılan durum, olay veya olgular katılımcıların düşünceleriyle bütüncül bir şekilde ele alınmaktadır (Ekiz, 2009; Yıldırım ve Şimşek, 2013; McMillan, \& Schumacher, 2010). Durum çalışması, güncel bir olguyu kendi yaşam çerçevesi içinde çalışan, olgu ve içinde bulunduğu içerik arasındaki sınırların kesin hatlarıyla belirgin olmadı $\breve{g}_{1}$ ve birden fazla kanıt veya veri kaynağının mevcut olduğu durumlarda kullanılan bir araştırma yöntemidir (Yin, 1994). Çalışma birden çok birey üzerinde yürütülmüştür. Ayrıca genel durum derinlemesine ortaya konulmaya çalışılmıştır. $\mathrm{Bu}$ sebepten dolayı çalışmada durum çalışması türlerinden bütünleşik durum çalışması tercih edilmiştir.

\section{2. Çalışma Grubu}

Çalışma grubunu yedi bayan üç erkek toplam 10 ortaokul matematik öğretmeni oluşturmaktadır. Mesleki deneyimleri 1 ile 6 yil arasında değişen ve bir devlet üniversitesinde lisansüstü eğitim yapan bu öğretmenlerden altıs1 matematiksel model kavramına daha önceden aşina olduklarını ancak derslerinde kullanmadıklarını dile getirmişlerdir. Diğer dört öğretmen ise model kavramının görsellik sunmak olduğunu ve mümkün olan konularda matematiksel modeli kullandıklarını ifade etmişlerdir. Yani matematiksel model ile ilgili bilgi veya deneyim sahibi olan ve Erzurum il ve ilçelerinde görev yapan 10 öğretmen gönüllülük esasına göre çalışma grubuna dahil edilmiştir. Amaçlı örnekleme yöntemleri içerisinde bulunan kolay ulaşılabilir durum örneklemesi ile belirlenen bu 10 ögretmenin etik kurallar dahilinde isimlerine yer verilmemiş, isimleri $\mathrm{O}_{1}, \ddot{\mathrm{O}}_{2}, \ldots, \mathrm{O}_{10}$ şeklinde kodlanmıştır.

\subsection{Veri Toplama Arac1}

Veriler yedi soru içeren bir bilgi testiyle toplanmıştır. Bilgi testi hazırlanırken matematiksel kavram yanılgıları göz önünde bulundurulmuş, özellikle matematiksel modellerde yer alan hatalar incelenmiştir. Kesir modelinde yer alan hatalarda kısıtlı algılama, cebirsel model, tablo modeli, şekil veya grafik modelinde yer alan hatalarda ise yanlış tercümeden kaynaklı kavram yanılgılarının olduğu (Özmantar, Bingölbali ve Akkoç, 2015) tespit edilmiştir. Bu sebeple bilgi testinde yer alan hatalı modellerde kavram yanılgıları ön planda tutulmuştur.

Araştırmacılar tarafından hazırlanan bilgi testinin kullanışlılığının öğrenilmesi, soruların test edilmesi ve araştırmacılara çalışma hakkında ön bilgi kazandırması amacıyla bir ortaokul matematik öğretmeniyle pilot çalışma yapılmıştır. Pilot çalışma sonucunda sekiz sorudan oluşan bilgi testindeki bir soru anlaşılmadığı için çıkarılmıştır.

\subsection{Verilerin Toplamas}

Araştırmacılar, testteki her bir soru için doğru ve hatalı iki çözüm oluşturmuşlardır. Farklı modeller kullanılarak hazırlanan bu çözümler, iki farklı çözüm kâğıdı şeklinde öğretmenlere sunulmuştur. Çözümlerin doğru ya da hatalı oluşu hakkında öğretmenlere bilgi verilmemiştir. Öğretmenlerden her iki çözüm kağıdında yer alan çözümleri değerlendirmeleri istenmiştir. Ayrıca bilgi testindeki birinci sorunun çözümünde sayma pulu modeli, ikinci sorunun çözümünde cebirsel ve tablo modeli, üçüncü ve altıncı sorusunun çözümünde ise kesir modeli kullanılmıştır. Dört ve beşinci soruda şekil modeli, yedinci soruda ise sayı doğrusu modelini içeren çözümler yer almaktadır. Kullanılan bilgi testi ekte verilmiştir. $\mathrm{Bu}$ süreçte öğretmenlere ilk olarak birinci çözüm kâğıdı verilmiştir. Öğretmenlerden burada yer alan doğru veya hatalı modellerle gerçekleştirilen çözümleri değerlendirmeleri istenmiştir. Yazılı olarak alınan bu değerlendirmelerde öğretmenler çözümün doğru mu yanlış mı yapıldığına odaklanmışlardır. Daha sonrasında ikinci çözüm kâğıdı öğretmenlere dağıtılmıştır. Birinci çözüm kâğıdıyla aynı soruları içeren ikinci çözüm kağıdında da doğru veya yanlış olduğu belirtilmeyen modellerle gerçekleştirilmiş çözümler bulunmaktadır. Benzer şekilde ikinci çözüm kâğıdındaki soru çözümleri için de öğretmenlerin yazılı görüşleri alınmıştır

Yazılı cevaplar alındıktan sonra öğretmenlerin çözümlere yönelik değerlendirmeleri bir araştırmacı ve matematik eğitimcisi olan üç uzman tarafindan incelenmiştir. $\mathrm{Bu}$ incelemeler sonucunda öğretmenlerin yazılı olarak verdikleri cevaplarda anlaşılamayan noktaların olduğu görülmüştür. Bu nedenle her bir öğretmenle bireysel olarak görüşmeler yapılmıştır. Görüşme, öğretmenlerin iki çözüm kâğıdındaki yazılı açıklamalarıyla ilgili olup yazılı cevaplardan 1 hafta sonra yapılmıştır. "Illk soru için doğru demişsiniz. Şimdi bize neden doğru olduğunu da ifade eder misiniz?" veya "Peki şimdi nasıl bir değerlendirme yaparsınız?” gibi sorular görüşmede öğretmenlere yöneltilmiştir. Yarı yapılandırılmış olarak planlanan görüşmede belirlenen sorular dışında, anlaşılmayan noktaları ortaya koymaya yönelik sorular da kullanılmıştır. Ses kaydına alınan görüşmeler 15-25 dakika aralığında sürmüştür. Yapılan görüşmeler öğretmenlerden de izin alınarak video kamera ile kayıt altına alınmıştır ve görüşme notları aynı gün içerisinde yazıya dökülmüştür.

\subsection{Verilerin Analizi}

$\mathrm{Bu}$ çalışmada verilerin analizinde içerik analizi kullanılmıştır. İçerik analizinde amaç, toplanan verileri açıklayabilecek kavramlara ve ilişkilere ulaşmaktır 
(Yıldırım ve Şimșek, 2013). İçerik analizinde temelde yapılan işlem, birbirine benzeyen verileri belirli kavramlar ve temalar çerçevesinde bir araya getirmek ve bunları okuyucunun anlayabileceği bir biçimde düzenleyerek yorumlamaktır. $\mathrm{Bu}$ çalışmada da içerik analizine tabi tutulan veriler, betimlemeler ve doğrudan alıntılarla desteklenerek okuyucuya sunulmuştur.

\section{6. İnanırlık ve Tutarlılık}

$\mathrm{Bu}$ araștırmanın bilimsel olarak inandırıcılığını sağlamak için öncelikle öğretmenlere isimlerinin hiçbir şekilde kullanılmayacağı belirtilerek, verdikleri yazılı cevapların ardından yüz yüze görüşmeler yapılmıştır. Yüz yüze görüşmelerde öğretmenlerin rahat edebileceği bir ortam oluşturulmuş ve cevaplarını ayrıntılı olarak verebilecekleri süre tanınmıştır. Araştırmanın amacı doğrultusunda seçilmiş olan ortaokul matematik öğretmenleriyle gerçekleştirilen görüşmeler, kendi istedikleri zaman diliminde yapılmıştır. Böylece öğretmenlerden daha doğru bilgi edinilmeye çalışılmıştır. Veri toplama sürecinde hem bilgi testi hem de bu teste bağlı olarak yüz yüze görüşmeler yapılmış ve toplanan verilerin tamamı alanında uzman olan üç matematik eğitimcisi tarafından incelenmiştir. Bu inceleme sonucunda elde edilen ortak kodlar araştırmada kullanılmıştır. Ortak olmayan kodlar bu üç uzman tarafindan tekrar değerlendirilmiştir. $\mathrm{Bu}$ değerlendirme sonucu, uzmanlar tarafindan görüş ayrılığı olmadan araştırmaya dair kodların son hali oluşturulmuştur. Bir araştırmacı ise farklı zaman dilimlerinde yaptığ kodlamaları karşılaştırmıştır. Böylece çalışmanın teyit edilebilirliği adına, uzmanlar tarafından da incelenerek kabul edilen bu kodlar araştırmada kullanılmıştır. Yapılan yüz yüze görüşmelerin ardından, öğretmenlerin ifade ettikleri cevaplar araştırmacı tarafından özetlenmiş ve katılımcı teyidi sağlanmıştır. Ayrıca öğretmenlerin görüşmelerinden doğrudan alıntılara yer verilerek ayrıntılı bir betimleme yapılmıştır.

\section{Bulgular}

$\mathrm{Bu}$ bölümde çalışmanın amacına uygun olarak sırasıyla sayma pulu, cebirsel-tablo, kesir, şekil ve sayı doğrusu modelini içeren sorulara ait bulgulara yer verilmiştir. Ayrıca her bir soru için birinci ve ikinci çözüm kâğıdındaki doğru ya da yanlış olduğu belirtilmeyen çözümler olduğu gibi sunulmuştur. Her bir model için oluşturulan içerik analizine ait tablolar, öğretmenlerin görüşme raporlarındaki doğrudan alıntılarıyla desteklenmiştir.

Bilgi testinin ilk sorusuna ait çözümler sayma pulu modeliyle gerçekleştirilmiştir. Öğretmenlere verilen çözüm kâğıtlarından biri sayma pulu modeli kullanılarak yapılan hatalı çözümü diğeri ise aynı model kullanılarak yapılan doğru çözümü vermektedir. Birinci soruya ilişkin her iki çözüm kâğıdındaki cevaplar Şekil 1'dedir.

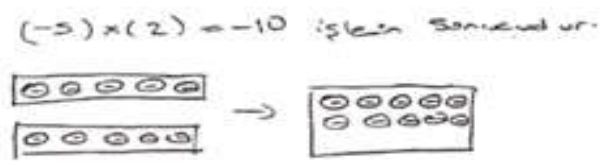

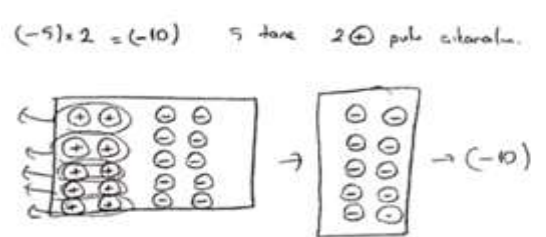

Şekil 1. 1. Soruya İlişkin Birinci ve İkinci Çözüm Kâğıdına Ait Cevaplar

Şekil 1 incelendiğinde birinci çözümde sayma pulları hatalı, ikinci çözümde sayma pulları doğru kullanılmıştır. Öğretmenlerin her iki çözümü değerlendirerek verdikleri cevaplara ait bulgular Tablo 1'de yer almaktadır.

Tablo 1. Öğretmenlerin 1. Soru İçin Gerçekleştirilen Çözümleri Doğru veya Yanlış Kabul Etme Gerekçelerine İlişin Kodlar

\begin{tabular}{|c|c|c|}
\hline & Birinci çōezüm & İinci çözuim \\
\hline \multirow{4}{*}{ Cöruinui değru kahul edenler } & $\overline{\mathrm{O}}_{1}, \overline{\mathrm{O}}_{2}, \overline{\mathrm{O}}_{3}, \overline{\mathrm{O}}_{4}, \overline{\mathrm{O}}_{\mathrm{s}}, \overline{\mathrm{O}}_{6}, \overline{\mathrm{O}}_{\mathrm{T}}, \overline{\mathrm{O}}_{\mathrm{s}}$ & $\overline{0}_{3}, \bar{O}_{5}$ \\
\hline & \multicolumn{2}{|c|}{ Gerelkpeler } \\
\hline & $\begin{array}{l}\text { Tsplama ile ilisglentrme } \\
\overline{\mathrm{O}}_{2} \overline{\mathrm{O}}_{3} \overline{\mathrm{O}}_{3}\end{array}$ & \multirow[t]{2}{*}{ 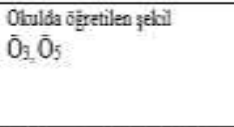 } \\
\hline & 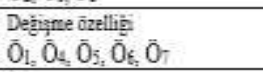 & \\
\hline \multirow{6}{*}{ Çōrünui yanlụ babul edenler } & $\bar{O}_{9}$ & $\overline{\mathrm{O}}_{1}, \overline{\mathrm{O}}_{2}, \overline{\mathrm{O}}_{4}, \overline{\mathrm{O}}_{\xi}, \overline{\mathrm{O}}_{z_{2}}, \overline{\mathrm{O}}_{2}, \overline{\mathrm{O}}_{9}$ \\
\hline & \multicolumn{2}{|c|}{ Gerekçeler } \\
\hline & \multirow[t]{4}{*}{$2 \mathrm{x}(-5)$ in modeli $\left(0_{y}\right)$} & $\begin{array}{l}\left({ }^{+}\right) \text {pullarn gerehsiz kL"lisnims } \\
\left(\bar{O}_{2}, \bar{O}_{;}\right)\end{array}$ \\
\hline & & 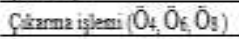 \\
\hline & & Alizhaser gĩaterin $\left(\overline{\mathrm{O}}_{1}\right)$ \\
\hline & & Toplama isteni $\left(0_{7}\right)$ \\
\hline
\end{tabular}

Tablo 1 incelendiğinde hatalı model içeren birinci çözüm ile doğru model içeren ikinci çözümün her ikisini de doğru kabul eden iki öğretmen; her ikisini de yanlış kabul eden bir öğretmen olduğu görülmektedir. Ayrıca Ö ile ilgili hiçbir bilgi sahibi olmadığını ifade ederek, herhangi bir açıklama yapmak istememiştir.

Hatalı model içeren birinci çözümü doğru kabul edip değişme özelliği ile ilişkilendiren Ö5'in yüz yüze görüşmede ifade ettiği açıklama aşağıdaki şekildedir.

“...burada 2 tane - 5 olarak düşünülmüs doğru dedim. Bir de biliyoruz ki çarpma işleminde değişme özelliği var. $O$ yüzden doğru kabul edilebilir."

Hatalı model içeren birinci çözümü yanlış kabul eden tek kişi olan Ö9'un görüşmede ifade ettiği açıklama şu şekildedir:

"Şimdi burada ilk ifade edilen tamsayı grup sayısın gösterir. Yani aslında bu, -5 tane 2 demektir. Ama çözümde 2 tane -5 olarak düşünülüp $2 x$ (-5) modellenmiştir. O yüzden bence yanlış bu. Gerçi çarpma işleminde yer değiştirme var ama modellemesi biraz sıkıntıll, farklı yani."

Doğru model içeren ikinci çözümün doğruluğunu okullarda öğretilen şekil olmasına bağlayan Ö3'ün yüz yüze görüşmede ifadeleri aşağıda yer almaktadır:

"Bizim okullarda çocuklara gösterdiğimiz modelleme şeklinde gösterilmiş. O yüzden doğru. Aslında bu çözüm çok sıkıntıll. Ben olsam diğer çözümü tercih ederim."

Doğru model içeren ikinci çözümü hatalı kabul edip bunu çıkarma işlemi ile ilişkilendiren Ö4'ün bu çözümle ilgili düşünceleri şu şekildedir: 
"Sanki bu çözüm bu işleme ait değil gibi. Sifir oluşmuş. Bunlarl nerede kullantyorduk. Bir hatırlıyım. Sayma pullarını biraktık artık biz ögretmiyoruz. Aslında bu bir çıkarma işlemidir. Sıfırdan +10'u çıkarmış, -10 kalmış. Evet, bu bir çıkarma işlemidir."

Bilgi testinin ikinci sorusu cebirsel-tablo modeli kullanılarak çözülmüştür. Verilen iki çözüm kâğıdında yer alan, doğru ya da yanlış olduğu belirtilmeyen çözümler bu modelle gerçekleştirilmiştir. İkinci soruya ilişkin cevaplar Şekil 2'de sunulmuştur.

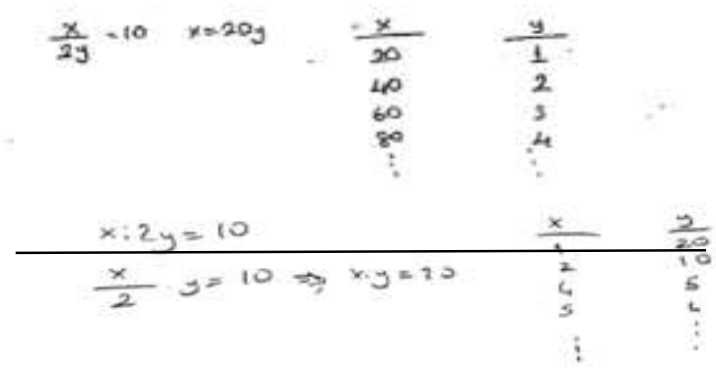

Şekil 2. 2. Soruya İlişkin Birinci ve İkinci Çözüm Kâğıdına Ait Cevaplar

Şekil 2 incelendiğinde cebirsel-tablo modeliyle gerçekleştirilen çözümlerin birincisi doğru ikincisi yanlıştır. Çözümleri değerlendiren öğretmenlerin verdikleri cevaplara göre oluşturulan Tablo 2 aşağıdaki şeklidedir.

Tablo 2. Öğretmenlerin 2. Soru İçin Gerçekleştirilen Çözümleri Doğru veya Yanlış Kabul Etme Gerekçelerine İlişin Kodlar

\begin{tabular}{|c|c|c|}
\hline & Birinci çüzüm & İinci çōrün \\
\hline \multirow{3}{*}{ Çörümi doğrn kabul edenler } & $\bar{O}_{4} \bar{O}_{i}$ & $\overline{\mathrm{O}}_{\mathrm{l}}, \overline{\mathrm{O}}_{2}, \overline{\mathrm{O}}_{3}, \overline{\mathrm{O}}_{6}, \overline{\mathrm{O}}_{2}, \overline{\mathrm{O}}_{\mathrm{z}}, \overline{\mathrm{O}}_{3}, \overline{\mathrm{O}}_{\mathrm{n}}$ \\
\hline & \multicolumn{2}{|c|}{ Gerekceler } \\
\hline & 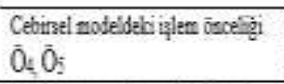 & 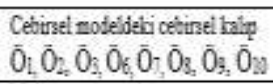 \\
\hline \multirow{3}{*}{ Ç̣̂zümỉ y̧arlạ kabul tdealer } & $\bar{O}_{1} \bar{O}_{2}, \bar{O}_{3}, \bar{O}_{2}, \bar{O}_{2}, \ddot{O}_{2}, \bar{O}_{2}, \bar{O}_{10}$ & $\bar{O}_{4} \bar{O}_{5}$ \\
\hline & \multicolumn{2}{|c|}{ Gerelseder } \\
\hline & 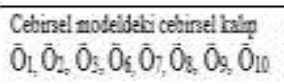 & 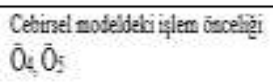 \\
\hline
\end{tabular}

Tablo 2 incelendiğinde öğretmenlerin sekizinin hatalı model içeren ikinci çözümü doğru kabul ettiği ve 2y'nin kalıp olarak alınması gerektiğini düşündükleri göze çarpmaktadır. Doğru model içeren birinci çözümü ise sadece iki öğretmenin doğru kabul ettiği ve bunun gerekçesi olarak da işlem önceliğini verdikleri görülmektedir. Ayrıca hem cebirsel hem de tablo modeli içeren her iki çözüm için altı öğretmenin her iki modeli de incelediği; diğer dördünün ise sadece cebirsel modele odaklandığı yüz yüze görüşmelerle tespit edilmiştir.

Doğru model içeren birinci çözümü doğru kabul edip bu çözümü cebirsel modeldeki işlem önceliği ile ilișkilendiren Ö' ${ }_{5}^{\prime}$ in yüz yüze görüşmede ifade ettiği açıklama şu şekildedir:

"Bu doğru çünkü bölme ve çarpma işlemi burada bir çarpma işlemi var (2 ile y arasını göstererek) eş önceliğe sahip. Eş önceliğe sahip işlemlerde biz ne diyoruz, baştan sonra doğru işlem yapılır. O yüzden bu işlem doğru. Önce 2 'ye bölecek sonra y ile çarpacak."
Hatalı model içeren ikinci çözümü doğru kabul edip bunu modeldeki cebirsel kalıp ile ilişkilendiren Ö̈' in yüz yüze görüşmede ifade ettiği açıklama aşağıdadır:

“2y bir kalıp olduğu için bu çözüm doğru. 2y’yi parçalaması çok yanlış. Bak o yüzden buradaki tablodaki değerler de olmasi gerektiği gibi. Yani oluşturduğu eşitliğe göre doğru değerleri verip bulmuş. Doğru yani.”

Doğru model içeren birinci çözümü yanlış kabul edip modeldeki cebirsel kalıp ile ilişkilendiren Ö̈'un düşünceleri aşağıda yer almaktadır:

“( $(x: 2) y=10$ şeklinde parantezle vermesi gerekir ki böyle parçalayabilelim. Yoksa olmaz. 2 y cebirsel ifadesi bir kalip. Niye parçalamış ki. Doğru değil yani ben öyle düşünüyorum."

Hatalı model içeren ikinci çözümü yanlış kabul edip cebirsel modeldeki işlem önceliği ile ilişkilendiren Ö$_{4}$ 'ün yüz yüze görüşmede yer alan ifadeleri şu şeklidedir:

“Şimdi burada 2y'yi kalıp olarak düşünmemeliyiz. 2.y olarak yani arada çarpma işlemi olarak düşünürsek işlem önceliğine göre çözülmüş̧ doğru. Bende aslında başlangıçta buna yanlış, diğerine doğru dedim ama sonra baktım ki yok burada aslında işlem önceliği var. O kalıp değil çarpma işlemi."

Üçüncü ve altıncı soru için gerçekleştirilen çözümlerde kesir modeli kullanılmıştır. Çözüm kâğıtlarında yer alan cevaplara Şekil 3'de yer verilmiştir.
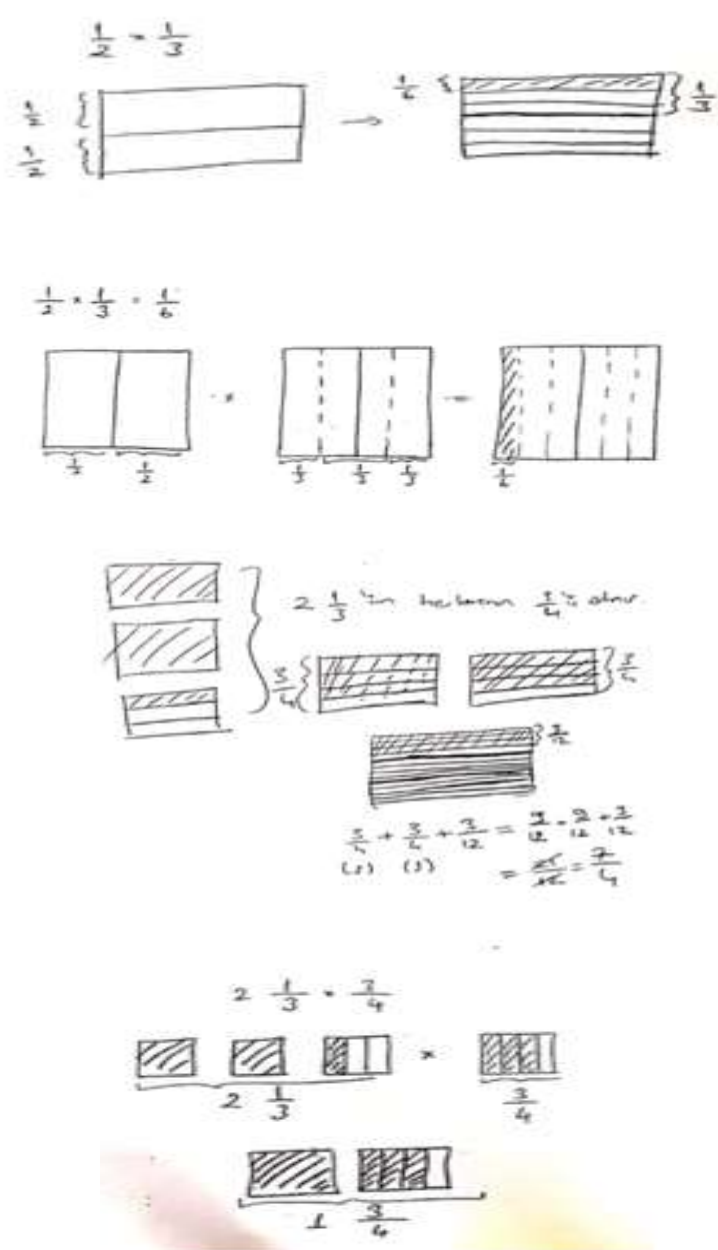
Şekil 3. 3 ve 6. Soruya İlişkin Çözüm Kâğıtlarında Yer Alan Cevaplar

Üçüncü soru için Şekil 3 incelendiğinde birinci çözüm doğru; ikinci çözüm yanlıştır. Bu soru için öğretmenlerin açıklamalarına dayanarak hazırlanan kodlama Tablo 3'de yer almaktadir.

Tablo 3. Öğretmenlerin 3. Soru İçin Gerçekleştirilen Çözümleri Doğru veya Yanlış Kabul Etme Gerekçelerine İlişin Kodlar

\begin{tabular}{|c|c|c|}
\hline & Birinci ç̣̆̉in & Ékinci çữia \\
\hline \multirow{3}{*}{ Cíximi dnğru babul edealer } & 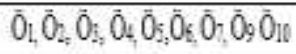 & $\bar{O}_{2}, \ddot{O}_{2}, \vec{O}_{4}, \ddot{O}_{\xi}, \bar{O}_{3}, \ddot{O}_{3}, \bar{O}_{\mathrm{n} n}$ \\
\hline & \multicolumn{2}{|c|}{ Gerekcheler } \\
\hline & 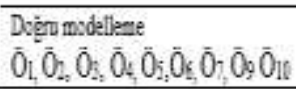 & 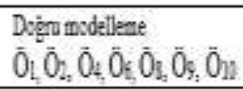 \\
\hline \multirow[b]{3}{*}{ Cỗüini ỵanhş kabal edenler } & $\bar{O}_{8}$ & $\overline{0}_{3,} \overline{0}_{3}, \bar{O}_{7}$ \\
\hline & \multicolumn{2}{|c|}{ Gerekceler } \\
\hline & $\begin{array}{l}\text { Yaaliz nodelleme } \\
\bar{O}_{8}\end{array}$ & 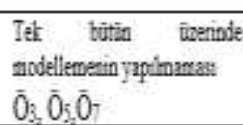 \\
\hline
\end{tabular}

Tablo 3 incelendiğinde doğru model içeren birinci çözüm ile hatalı model içeren ikinci çözümün her ikisini de doğru kabul eden altı öğretmen bulunduğu görülmektedir. Yapılan yüz yüze görüşmelerde ise bu altı öğretmenin tamamı iki çözüm arasında anlamsal bir fark olmadığını dile getirmişlerdir. Ayrıca $\ddot{\mathrm{O}}_{4}, \ddot{\mathrm{O}}_{5}, \mathrm{O}_{6}, \ddot{\mathrm{O}}_{7}$ ve $\mathrm{O}_{10}$ 'un başlang1çta aldığı kararları yüz yüze görüşmelerde değiştirdiği tespit edilmiştir. Doğru model içeren birinci çözümü doğru kabul eden $\mathrm{O}_{4}$ 'ün başlangıçta hatalı kabul edip daha sonra doğru kabul ettiği çözüme ilişkin yüz yüze görüşmede ifade ettiği açıklama şu şekildedir:

"Yani şimdi 1/2'i böyle gösterdiyse 1/3'i yatay göstermesi gerektiğini ifade ediyoruz. Böyle yaparsa ortak bölge olmaz. Aslında olur gibi. Evet olur. Doğru yapmış. Model doğru." Doğru model içeren birinci çözümü yanlış kabul edip yanlış modelleme olduğunu düşünen Ö${ }_{8}^{\prime}$ 'in yüz yüze görüşmedeki ifadelerine aşağıda yer verilmiştir: "Şimdi şöyle: Burada 1/2'i 3'e bölmüş ama sadece bir bölümün 1/6'ini taramış. Bu modele göre 2 tane 1/2'lik kısım var. İkisini de taraması gerekirdi. Yani şöyle: O zaman da sonuç 1/6 değil 2/6 olurdu. Bu da bize kullanılan modelin hatalı olduğunu gösteriyor."

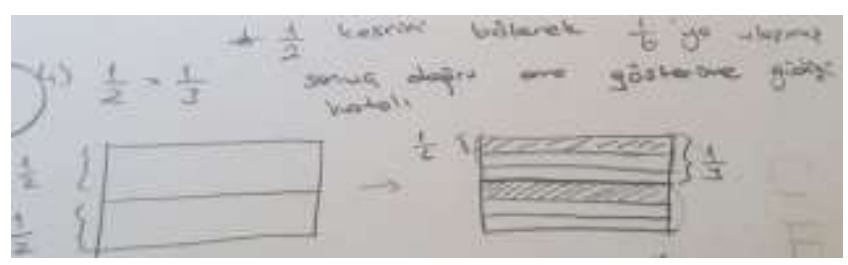

Şekil 4. 3.soruya ilişkin Ö8'in cevab1

Hatalı model içeren ikinci çözümü doğru kabul eden Ö̈'un yüz yüze görüşmesinden elde edilen ifadeler ise aşağıda bulunmaktadir:

“.... Aslında burada sonuç bulunmuş 1/6 diye. Sonuca göre model çizilmiş. Doğruyu bulmuş. ”

Hatalı model içeren ikinci çözümü başlangıçta doğru kabul edip yüz yüze görüşmede yanlış olduğunu fark eden Ö̈ ${ }_{7}$ ye ait düşünceler şu şekildedir:
"SSimdi burada 1/2 ile 1/3'in çarpımı yerine $1 / 3$ ile $1 / 2$ çarpılmış. Çünkü çarpmanın değişme özelliği vardır. Doğru aslında sıkıntı yok bence. Bir dakika. Burada her parça 1/3'e ayrılmamıs. Ayrı bütünler var. Araya çarpma işlemi koymuş. Bir dakika. Başlangıçta fark etmedim. Sonuç doğru olduğu için belki de fark etmedim. Ama bu doğru değil. Aynı bütün üstünde gösterilmesi gerekirdi."

Benzer şekilde altıncı soru için Tablo 3 incelendiğinde $2 \frac{\mathbf{1}}{\mathbf{3}} \times$ $\frac{3}{4}$ işlemi için kesir modeli kullanılarak çözümler gerçekleştirilmiştir. Birinci çözüm kâğıdına ait cevap doğru iken ikinci çözüm kâğıdına ait cevap yanlıştır. Öğretmenlerin çözümlerin doğru ya da yanlışlığını değerlendirirken kullandıkları gerekçeler Tablo 4'de yer almaktadir.

Tablo 4. Öğretmenlerin 6. Soru İçin Gerçekleştirilen Çözümleri Doğru veya Yanlış Kabul Etme Gerekçelerine İlişin Kodlar

\begin{tabular}{|c|c|c|}
\hline & Birinci çizum & İ̉nci çō̉rün \\
\hline \multirow{3}{*}{ Çörimui dığru babul edealer } & $\overline{\mathrm{O}}_{2}, \overline{\mathrm{O}}_{3}, \overline{\mathrm{O}}_{4}, \overline{\mathrm{O}}_{5}, \overline{\mathrm{O}}_{6}, \overline{\mathrm{O}}_{3}, \overline{\mathrm{O}}_{9} \overline{\mathrm{O}}_{10}$ & $\overline{0}_{2}$ \\
\hline & \multicolumn{2}{|c|}{ Gerelçeler } \\
\hline & $\begin{array}{l}\text { Doğru modellems } \\
\overline{\mathrm{O}}_{2}, \overline{\mathrm{O}}_{3}, \overline{\mathrm{O}}_{4}, \overline{\mathrm{O}}_{5}, \overline{\mathrm{O}}_{\mathrm{s}}, \overline{\mathrm{O}}_{3}, \overline{\mathrm{O}}_{9}, \overline{\mathrm{O}}_{10}\end{array}$ & $\begin{array}{l}\text { Dogèru nodeilleme } \\
\overline{0}_{2}\end{array}$ \\
\hline \multirow[b]{3}{*}{ Cörürūi ỵanlş kabul tdenler } & $\overrightarrow{0}_{1}, \overrightarrow{0}_{7}$ & $\begin{array}{l}\overline{0}_{3}, \bar{O}_{3}, \bar{O}_{4}, \bar{O}_{3}, \bar{O}_{6}, \bar{O}_{7}, \bar{O}_{3} \\
\overline{0}_{3}, \overline{0}_{2}\end{array}$ \\
\hline & \multicolumn{2}{|c|}{ Gerekçceler } \\
\hline & $\begin{array}{l}\text { Yanilş modelleme } \\
\overrightarrow{0}_{1}, \hat{0}_{7}\end{array}$ & 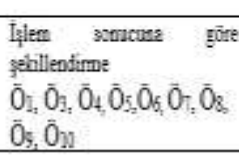 \\
\hline
\end{tabular}

Tablo 4 incelendiğinde doğru model içeren birinci çözüm ile hatalı model içeren ikinci çözümün her ikisini de doğru kabul eden bir öğretmen ve her ikisini de yanlış kabul eden iki öğretmen olduğu görülmektedir.

Doğru model içeren birinci çözümü doğru kabul eden Ös'in yüz yüze görüşmede ifade ettiği açıklama şu şekildedir:

"Şimdi tekrar bakınca soruya, çözüm süreci de içeriyor. Yani doğru bir modelleme yapılmış.”

Doğru model içeren birinci çözümü yanlış kabul eden Ö ${ }_{1}$ 'in yüz yüze görüşmedeki ifadeleri aşağıdaki gibidir:

"Aslında tek tek bakınca her birini doğru göstermiş ama sonra hepsini tek bir model üstünde göstermiyor. O yüzden bana doğru gelmedi. Yanlış olmuş."

Hatalı model içeren ikinci çözümü doğru kabul eden Ö 2 'nin yüz yüze görüşmedeki düşünceleri aşağıda yer almaktadır:

"Yani ilk kesri bileşik kesre çevirip çarpınca 7/4 çıkacak. O da 1 tam 3/4 zaten. Burada da o gösterilmiş. Tek tek kesirler görselleştirilmiş. Sonra da çarpılmış. Sonuç da doğru zaten. Doğru yani."

Hatalı model içeren ikinci çözümü yanlış kabul eden Ö 10 'un yüz yüze görüşmede ifade ettiği açıklama şu şekildedir:

"Şimdi burada önce işlem çözülmüş. Yani sonucu 1 tam 3/4 diye bulmuş. Sonra tutmuş bunu çizmiş. Yani modellememiş. Zaten bu modelleme çok da uygun değil kesirler de çarpma ve bölmede. Kullanilmamasl gerekiyor bence. Sonucu bulmuş işte. Ama gösterim doğru değil.", 
Dört ve beşinci soruların çözümü için şekil modeli kullanılmıştır. Bu sorular için her iki cevap kâğıdında yer alan çözümler Şekil 5'deki gibidir.

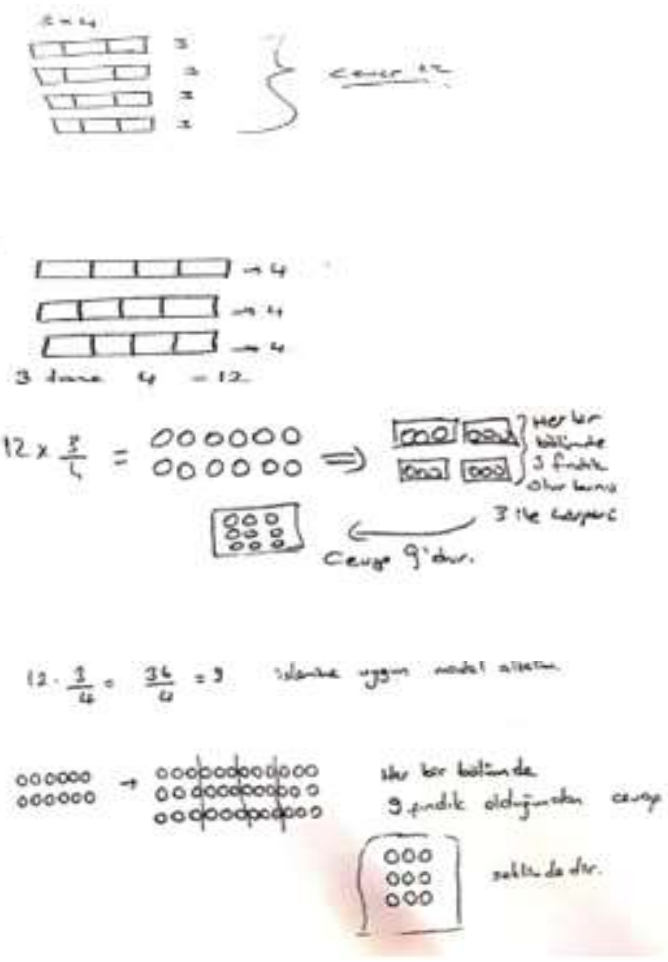

Şekil 5. 4 ve 5. Soruya İlişkin Çözüm Kâğıtlarında Yer Alan Cevaplar

Dördüncü soru için Şekil 5 incelendiğinde birinci çözüm kâğıdındaki cevapta şekil modeli hatalı anlamlandırılmış; ikinci çözüm kâğıdında ise modelin doğru kullanımıyla doğru cevaba ulaşılmıştır. Bu çözümleri değerlendiren öğretmenlerin görüşmelerinden elde edilen kodlar Tablo 5 'de yer almaktadir.

Tablo 5. Öğretmenlerin 4. Soru İçin Gerçekleştirilen Çözümleri Doğru veya Yanlış Kabul Etme Gerekçelerine İlişin Kodlar

\begin{tabular}{|c|c|c|}
\hline & Birinci çivim & İkinci çörtīa \\
\hline \multirow{4}{*}{ 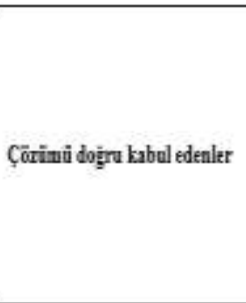 } & $\bar{O}_{2}, \bar{O}_{3}, \bar{O}_{4}, \bar{O}_{2}, \bar{O}_{3}, \bar{O}_{2}, \bar{O}_{n}$ & $\begin{array}{l}\vec{O}_{2}, \ddot{O}_{3}, \bar{O}_{4}, \bar{O}_{5}, \bar{O}_{6}, \bar{O}_{7}, \bar{O}_{2}, \\
\bar{O}_{3}, \bar{O}_{n}\end{array}$ \\
\hline & \multicolumn{2}{|c|}{ Gerekceler } \\
\hline & $\begin{array}{l}\text { Degisme coeligi } \\
\overline{0}_{2}, \bar{O}_{3}, \bar{O}_{4}, \overline{0}_{7}, \bar{O}_{3}, \bar{O}_{9}\end{array}$ & $\begin{array}{l}\text { Dogirs nodetlene } \\
\overrightarrow{0}_{2}, \overrightarrow{0}_{3}, \bar{O}_{4}, \overline{0}_{5}, \bar{O}_{6}, \bar{O}_{7}, \overrightarrow{0}_{2} \text {; } \\
\overrightarrow{0}_{9}\end{array}$ \\
\hline & $\begin{array}{l}\text { Degèro model } \\
\bar{O}_{10}\end{array}$ & $\begin{array}{l}\text { Degigne özetlig } \\
\overrightarrow{0}_{1:}\end{array}$ \\
\hline \multirow{4}{*}{ Çözimi yanlạ babıl edenler } & $\bar{O}_{2} \bar{O}_{5} \bar{O}_{6}$ & $\overrightarrow{0}_{1}$ \\
\hline & \multicolumn{2}{|c|}{ Gereksceler } \\
\hline & $\begin{array}{l}\text { Kesir modeh } \\
\overline{0}_{1}\end{array}$ & \multirow{2}{*}{$\begin{array}{l}\text { Kesir modeli } \\
\hat{O}_{1}\end{array}$} \\
\hline & $\begin{array}{l}\text { Parhy modeleme } \\
\overline{0}_{5}, \bar{O}_{6}\end{array}$ & \\
\hline
\end{tabular}

Tablo 5'e incelendiğinde hatalı model içeren birinci çözüm ile doğru model içeren ikinci çözümün her ikisini de doğru kabul eden yedi öğretmen ve her ikisini de yanlış kabul eden bir öğretmen olduğu görülmektedir. Her ikisini de doğru kabul eden öğretmenlerin tamamının çarpmanın değişme özelliğinden dolayı çözümler arası fark bulunmadığını ifade ettikleri görülmüştür.

Hatalı model içeren birinci çözümü doğru kabul edip değişme özelliği ile ilişkilendiren $\mathrm{O}_{2}$ 'nin yüz yüze görüşmede ifade ettiği açıklama şu şekildedir:

"Soruda $3 \times 4$ ün modellenmesini istemiş. Burada $3 x 4$ ya da $4 x 3$ fark etmez. İkisinde de 12 parça oluşuyor sonuçta. Çarpmanın değişme özelliğini de kullanarak doğru dedim.'

Hatalı model içeren birinci çözümü yanlış kabul eden Ö6'nın yüz yüze görüşmedeki açıklaması aşağıdaki gibidir:

"3x4 demek 3 tane 4 demektir. Ama burada 4 tane 3 var. Yani burada $4 \times 3$ modellenmiş. O yüzden yanlış model çizilmiş yani."

Doğru model içeren ikinci çözümü doğru kabul edip değişme özelliği ile ilişkilendiren Ö 10 'un yüz yüze görüşmede ifadeleri aşağıda yer almaktadır:

“... Aslında diğer çözüm (1 nolu çözüm) doğru olan. $3 \times 4$ ün doğru modellemesi o. Çünkü önce bir bütünü 3 parçaya ayırmış ve ondan 4 tane almış. Doğru. Diğgeri ise (2 nolu çözüm) $4 \times 3$ ün modellemesi. Yani önce bir bütünü 4'e bölmüss ondan 3 tane almış demektir. Ama çarpmanın değişme özelliği var. O yüzden bu da doğru yani."

Doğru model içeren ikinci çözümü yanlış kabul edip çözümü kesir modeli ile ilişkilendiren Ö ${ }_{1}^{\prime}$ 'in yüz yüze görüşmede ifade ettiği açıklama şu şekildedir:

“Biz normalde bu modeli kesirler için kullanıyoruz. Bütünü parçalara ayırmış ve parçayı da kesir olarak ifade ediyoruz. Ama burada parçaları doğal sayı olarak ifade etmiş. $O$ yüzden bana hiç doğru gelmedi. Bu da ögrenciyi hataya götürür gibi geldi bana. Bütünü parçalara ayırmışsa kesir olarak ifade etmesi gerekiyordu."

Tablo 5 incelendiğinde beşinci soruda da dördüncü soru gibi çözümünde şekil modeli kullanılan cevaplar yer almaktadır. Doğru ya da yanlış olduğu belirtilmeyen çözümlerin değerlendirilmesine yönelik gerçekleştirilen görüşmelerden elde edilen bulgular Tablo 6'da yer almaktadır.

Tablo 6. Öğretmenlerin 5. Soru İçin Gerçekleştirilen Çözümleri Doğru veya Yanlış Kabul Etme Gerekçelerine İliş̧in Kodlar

\begin{tabular}{|c|c|}
\hline & Birneci çizüm \\
\hline \multirow{3}{*}{ Çärümi doğru kabıl edealer } & 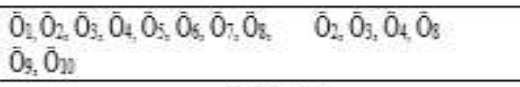 \\
\hline & Gerekçeler \\
\hline & 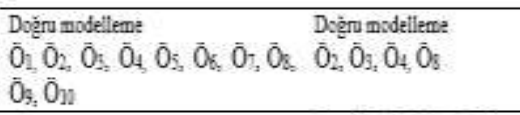 \\
\hline & $\overline{\mathrm{O}}_{\mathrm{l},}, \overline{\mathrm{O}}_{5,}, \overline{\mathrm{O}}_{\mathrm{k},} \overline{\mathrm{O}}_{\mathrm{z}}, \overline{\mathrm{O}}_{2,}, \overline{\mathrm{O}}_{10}$ \\
\hline & Gerekcteler \\
\hline
\end{tabular}

Tablo 6 incelendiğinde doğru model içeren birinci çözümü bütün öğretmenlerin doğru kabul ettiği ve yanlış kabul eden öğretmenin bulunmadığı görülmektedir. Bununla beraber hatalı model içeren ikinci çözümü de doğru kabul eden dört öğretmen bulunmakta ve bunu rasyonel sayılarda işlem sırası olmadığı ile ilişkilendirmektedirler. 
Doğru model içeren birinci çözümü doğru kabul eden Ö6'nın yüz yüze görüşmede ifade ettiği açıklama şu şekildedir:

“Bu sorudaki kavram kesir. Kesrin mantığ da budur. Önce bütünü 4 gruba ayırıp, 3 parçasını almamız lazım. Doğru yapmiş. Görseli de doğru göstermiş."”

Hatalı model içeren ikinci çözümü doğru kabul eden $\mathrm{Ö}_{3}{ }^{\prime}$ ün yüz yüze görüşmedeki açıklamaları aşağıdaki gibidir:

“Doğru çözüm. 12'yi 3 sıra halinde çizip aslında 3 'le çarpmış. Sonra da 4 gruba ayırmış. Her grupta da 9 findık olduğunu göstermiş. Doğru. Iş̧lemde de modelde de sıkıntı yok."

Hatalı model içeren ikinci çözümü yanlış kabul eden Ög'un yapılan görüşmedeki ifadeleri aşağıda yer almaktadır:

“...zaten 4 te 4 ü 12 findık. Yani tamamı 12. Bizden 4 te 3 'ü isteniyor. Azaltmamız lazım. Isslem olarak sanki doğru gibi görünüyor olabilir. İkisinin sonucunu 9. Ama bütün 12. Onu 36 'ya çıkaramaz. O yüzden yanlıs."

Bilgi testinin yedinci sorusuna ait çözümler sayı doğrusu modeliyle gerçekleştirilmiştir. Öğretmenlere verilen çözüm kâğıtlarından biri sayı doğrusu modeli kullanılan yanlış çözümü diğeri ise aynı model kullanılarak cevaplandırılan doğru çözümü içermektedir. Son soruya ilişkin her iki çözüm kâğıdındaki cevaplar Şekil 6'da bulunmaktadır.
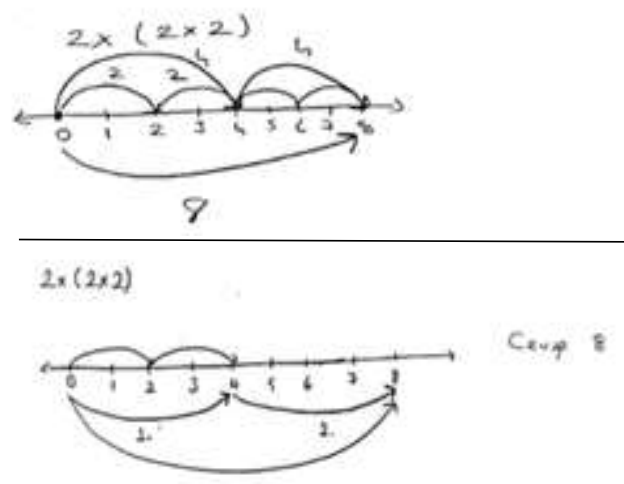

Şekil 6. 7.Soruya İlişkin Birinci ve İkinci Çözüm Kâğıdına Ait Cevaplar

Şekil 6 incelendiğinde birinci cevapta sayı doğrusu modeli hatalı, ikinci cevapta sayı doğrusu modeli doğru kullanılarak çözüm yapılmıştır. Öğretmenlerin her iki çözümü değerlendirerek verdikleri cevaplara ait kodlama Tablo 7'de yer almaktadır.

Tablo 7. Öğretmenlerin 7. Soru İçin Gerçekleştirilen Çözümleri Doğru veya Yanlış Kabul Etme Gerekçelerine İlişin Kodlar

\begin{tabular}{|c|c|c|}
\hline & Bírnci coinuim & İkinci çōüin \\
\hline \multirow{3}{*}{ Çözümi dog̣rn kabul edealer } & $\begin{array}{l}\bar{O}_{2} \bar{O}_{3}, \bar{O}_{4}, \bar{O}_{3}, \bar{O}_{;}, \tilde{O}_{3}, \tilde{O}_{\xi_{4}} \\
\bar{O}_{n}\end{array}$ & 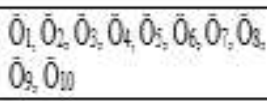 \\
\hline & \multicolumn{2}{|c|}{ Gerekcpeler } \\
\hline & 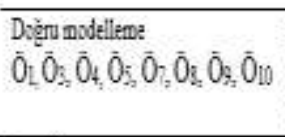 & $\begin{array}{l}\text { Doegrom modelleme } \\
\bar{O}_{1}, \bar{O}_{2}, \overline{0}_{3}, \bar{O}_{4}, \bar{O}_{3}, \bar{O}_{6}, \bar{O}_{7}, \bar{O}_{3}, \\
\bar{O}_{3}, \bar{O}_{10}\end{array}$ \\
\hline \multirow{3}{*}{ Ç̣zimin Ṭantạ kabul edenler } & $\overline{0}_{2} \overline{0}_{6}$ & \\
\hline & \multicolumn{2}{|c|}{ Gerekpealer } \\
\hline & $\begin{array}{l}\text { Gereksiz sịtem gôsterimi } \\
\bar{O}_{2}, \bar{O}_{6}\end{array}$ & \\
\hline
\end{tabular}

Tablo 7 incelendiğinde hatalı model içeren birinci çözümü yanlış kabul eden iki öğretmen olduğu ve doğru model içeren ikinci çözümü bütün öğretmenlerin doğru kabul ettiği görülmektedir.

Hatalı model içeren birinci çözümü doğru kabul eden $\mathrm{O}_{3}$ 'ün yüz yüze görüşmede ifade ettiği açıklama şu şekildedir:

"Burada önce 2x2 yapılmış. Bundan 2 tane istediği için de iki kere $2 x 2$ gösterilmiş. Zaten sıkıntı yok. İki çözüm de aynı fark yok. Doğru yani ikisi de."

Hatalı model içeren birinci çözümü yanlış kabul eden Ö$_{2}$ 'nin yüz yüze görüşmede ifade ettiği açıklamaya aşağıda yer verilmiştir:

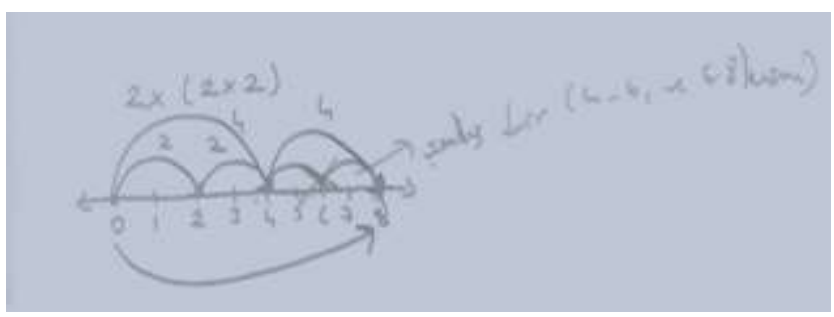

Şekil 7. 7.soruya ilişkin Ö${ }_{2}$ 'nin cevab1

"Burada şu ikinci kısmı gereksiz yere çizip göstermiş. Çünkü burada 4 tane 2 demiyor."

Doğru model içeren ikinci çözümü doğru kabul eden Ö.'nın görüşmedeki ifadesi şu şekildedir:

"Doğru. Bizim öğrettiğimiz de bu. Sikıntı yok. Doğru modellenmiş."

\section{Sonuç, Tartışma ve Öneriler}

Matematik öğretiminde bilimsel olayları ve problemleri model kullanarak örneklerle, şekillerle, gösterilerle ve resimlerle açıklamak, öğrencilerin hayal gücünü ve yaratıcılığını geliştirmenin yanı sıra (Işık ve Mercan, 2015) soyut olarak kabul edilen matematik dersini de somutlaştırmaya yardımcı olacaktır. Bu çalışmada ortaokul matematik öğretmenlerinin çeşitli modeller üzerinde yapılması muhtemel olan hataları belirleyebilme ile bu hataları anlamlı bir şekilde açıklayabilme durumları incelenmiş ve bu amaç doğrultusunda yedi soruluk bir bilgi testi kullanılmıştır. Araştırmacılar, bu testteki her bir soru için doğru ve hatalı iki çözüm gerçekleştirmişlerdir. Farklı modeller kullanılarak hazırlanan bu çözümler, doğru ya da hatalı olduğu belirtilmeden iki farklı çözüm kâğıdı şeklinde 
öğretmenlere sunulmuştur. Öğretmenler her iki çözüm kâğıdında yer alan çözümleri değerlendirmişlerdir.

Bilgi testindeki soruların çözümünde sayma pulu, cebirseltablo, kesir, şekil ve sayı doğrusu modeli kullanılmıştır. Öğretmenlerin gerçekleştirilen çözümleri değerlendirirken doğru ya da hatalı çözümü ayırt etmede zorlandıkları tespit edilmiştir. Bazı öğretmenlerin hem hatalı hem de doğru çözümü doğru ya da yanlış kabul ettiği görülmüştür. Ayrıca yapılan görüşmelerde öğretmenlerin doğru ya da hatalı olduğunu düşündüğü çözümler üzerine yeterli açıklama yapamadıkları fark edilmiştir. Gerek öğrenen ve gerekse öğretici çözümü doğru yapmanın yanı sıra yapılan bir çözümü değerlendirebilme yani neden doğru ya da neden yanlış olduğunu açıklayabilme yetisine sahip olmalıdır. $\mathrm{Bu}$ durum yapısalcılık ilkesi gereğince de vurgulanan, doğruları tekrarlayan pozitif bilginin yeterli olmadığ 1 ; tam anlamıyla öğrenmenin sağlanabilmesi için negatif bilginin de gerekli olduğu savını akla getirmektedir. Negatif bilgiye sahip olmak ise hataları anlamlandırabilmekten geçmektedir (Dalehefte, Seidel, \& Prenzel, 2012; Heinze, 2005; Parviainen, \& Eriksson, 2006). Bu çalışmada ortaokul matematik öğretmenlerinin modellerdeki hataları anlamlandıramadıkları görülmüştür. Çalışma sonucu göz önüne alındığında öğretmenlerin model oluşturma konusundaki negatif bilgi düzeylerinin geliştirilmesi gerektiği düşünülmektedir.

Öğretmenlerin doğru ve hatalı çözüm arasındaki farkı anlamada zorlanmaları, öğretmenlerin model konusunda kavramsal bilgiye sahip olmadıklarını düşündürmüştür. Zaten kullanılan modellere "doğru modelleme" veya "yanllş modelleme" şeklinde gerekçe sunmaları bunun bir göstergesi olarak kabul edilmiştir. Yapılan çalışmalar göz önüne alındığında hataları belirleyebilmek, öğretmenlerin kavramsal bilgi seviyelerini arttırabilir. Bireylere hataları belirleyebilme imkânı verilir ve bu konuda bireyler desteklenirse kavramsal bilgi düzeyi gelişim gösterebilir (Borasi, 1986; 1989; 1994; Özkaya, 2015). Benzer şekilde Ginat (2003) hataların doğru çözümü kavramada anahtar rol oynadığını ifade etmiştir. Borasi (1989) hatalar kullanarak edinilen bilginin kalıcı olduğunu ve bu bilgiye karşı merak ve ilginin daha fazla olduğunu ortaya koymuştur.

Sayma pulu modeline yönelik öğretmenlerin değerlendirmeleri incelendiğinde, hatalı model içeren çözümü doğru kabul eden öğretmenlerin çoğunlukta olduğu görülmektedir. Soruda yer alan ifadenin müfredatta olmadığına değinen öğretmenlerin yanı sıra sayma pulu modelinin kullanımının gereksizliğini düşünen öğretmenlerin de olduğu tespit edilmiştir. Özellikle sayma pulu modelini anlamlandırmada öğretmenlerin oldukça zorlandıkları ortaya çıkarılmıştır. Benzer bir çalışmada Durmaz (2017), matematik öğretmenleri ile adaylarının tamsayılarla dört işlemi sayma pullarıyla modelleme çalışmasında hem öğretmenlerin hem de öğretmen adaylarının tam sayılarla toplama işleminin modellenmesinde diğer işlemlere göre daha başarılı oldukları fakat çıkarma, çarpma ve bölme işlemlerini modellemede ise zorluk yaşadıklarını belirlemiş̧ir. BostanIşıksal (2015)'ın negatif sayılara ilişkin zorluklar, kavram yanılgıları ve bu kavram yanılgıların giderilmesine yönelik yapmış olduğu çalışmasında model kullanımının negatif sayılarda işlemlerde ezber bilgilerden öğrencilerin kurtulacağını ve bilgilerin anlam kazanacağını belirtmiştir.
Çünkü model ile anlaşılması güç olan bu soyut olgular daha anlaşılır olmakta ve özellik içselleştirilmektedir.

Cebirsel modele yönelik yapılan görüşmeler bağlamında öğretmenlerin cebirsel ifadeler arasında yer alan işlemlerde, işlem önceliğini dikkate almadıkları görülmüştür. Ayrıca öğretmenlerin katsayı ile değişkenin bir cebirsel kalıp oluşturduğunu düşündükleri anlaşılmaktadır. Cebirsel model ve tablo modelinin aynı anda bulunduğu soruda öğretmenler, tablo modelinden ziyade cebirsel model üzerindeki çözüm sürecine odaklanmışlardır. Altı öğretmen tabloda yer alan verilerin doğru ya da hatalı olduğuna dair geri bildirimde bulunmuş, diğer dört öğretmen ise tablo modeline dair herhangi bir açıklamada bulunmamıştır. Amaç ve Dikiş-Kabar (2019), ortaokul matematik öğretmeni adaylarının cebirde harflerin kullanımı ve cebirsel işlemler konusunda öğrenci hatalarına yönelik farkındalıklarını, öğretmen adaylarının öğrenci hatalarına yönelik tahminleri ve öğrenci düşünme şekilleri bilgilerine yönelik çalışmalarında; bazı temel öğrenci hatalarının farkında olduklarını fakat öğrencilerden gelebilecek farklı tür hatalara yönelik farkındalık düzeylerinin düşük olduğunu belirlenmiştir. Bu çalışmada da öğretmenlerin cebirsel ifadelerde yer alan harf ve sayılar arasında işlem önceliğini göz ardı edip, gruplandırdıkları görülmüş; dolayısıyla öğrencilerinin de benzer hatalara yönelik farkındalığa sahip olmayacakları görülmüştür. Bu sebeple matematik eğitimcilerine öğretmen adaylarının öğrenci hatalarına yönelik farkındalıklarını geliştirmek amacıyla önce kendilerinin bu hataların farkında olmaları ve buna bağlı olarak da öğrenme ortamını tasarlamaları önerilmektedir.

Kesir modeline yönelik üçüncü ve altıncı soruların ikinci çözümü hatalı model içermektedir. Her iki soru için de ikinci çözümü doğru kabul eden sadece bir öğretmen bulunmaktadır. Bu öğretmen her ikisi için de kesirlerin tek tek gösteriminin doğru olduğunu ve sonucun da olması gereken şekilde gösterildiğini ifade etmiştir. Bahsi geçen öğretmenin tek bir şekil üzerinde kesir işleminin gösterilmesinin gerekliliğini göz ardı ettiği görülmüştür. Ayrıca üçüncü soruda hatalı model içeren çözümü doğru kabul edip benzer işlemin yapıldığı altıncı sorudaki hatalı model içeren çözümü doğru kabul etmeyen altı öğretmen olduğu tespit edilmiştir. $\mathrm{Bu}$ durum göz önüne alındığında kesir modelinin öğretmenler tarafindan anlamlandırılamadı $\breve{g} 1$ söylenebilir. Bu noktada Alacacı (2015) kesir öğretimi konusunda somut modellerin, Lesh, Post ve Behr (1987)'nin resim, diyagram, sözlü semboller ve yazılı sembollerin matematiksel öğrenme ve problem çözme sürecinde yardımcı olacağını vurgulamışlardır.

Şekil modeline yönelik dördüncü ve beşinci sorulardan elde edilen sonuçlar 1șı̆ı̆ında öğretmenlerin hatalı model içeren çözüm ile doğru model içeren çözüme yönelik verdikleri cevapların benzer olduğu ve çoğunlukla da her iki çözümü de doğru kabul ettikleri görülmüştür. Beşinci soruda yer alan işleme yönelik verilen modelde öğretmenlerin çarpma işleminin değişme özelliğine bağlı olarak sonucun aynı olduğunu dolayısıyla da bu çözümü doğru kabul ettikleri; sürecin farklı olduğunu göz önünde bulundurmadıkları belirlenmiştir. Lean ve Clements (1981) de problem çözerken şekilsel modellerini kullanan öğrencilerin çözümlerini daha iyi anladıklarını dolayısıyla şekil 
modellerinin öğretimde yararlı olacağı kanaatini vurgulamışlardır (Akt. Lowrie, 2001).

Sayı doğrusu modeli kullanılarak gerçekleştirilen çözümleri değerlendiren öğretmenlerden hatalı model içeren çözümü yanlış kabul eden sadece iki öğretmenin bulunduğu göze çarpmaktadır. Doğru model içeren çözümü bütün öğretmenlerin doğru kabul etmesine rağmen sekiz öğretmenin hatalı model içeren çözümü de doğru kabul ettiği görülmüştür. Kesirlerin sayı doğrusu modeli üzerindeki gösteriminde, öğrencilerin bütünü parçalara ayırmada zorluk çektikleri bilinmektedir (Bright, Behr, Post, \& Wachsmuth, 1988). Pesen'e (2008) göre de kesirlerin gösteriminde kullanılan sayı doğrusu modelini çizme çalışmalarında bütünün eş parçalara ayrılması gerektiği önemle vurgulanmalıdır. Ayrıca, kesirlerin sayı doğrusu üzerindeki gösteriminde, bölge modelinde olduğu gibi, bütünün kaç parçaya bölüneceği ve bu parçalardan kaç tanesinin seçileceği dikkate alınması gerekir. Bu doğrultuda mümkün olduğunca modelin doğru çizimi için öğrenciler cesaretlendirilmelidir.

Diğer bir ifadeyle, kesirlerin sayı doğrusu üzerindeki şekilsel anlamının göz ardı edilmemesi için sembollere geçişte aceleci davranılmamalıdır.

Çalışmanın en önemli sonuçlarından biri öğretmenlerin doğru ve hatalı çözüm arasındaki farkı anlamada zorlanmalarıdır. $\mathrm{Bu}$ durum kavramsal bilgi eksikliğine işaret etmektedir. Wanjala ve Orton (1996) tarafindan yapılan araştırmanın sonuçlarına göre öğretmenlerin öğrencilerin yapabilecekleri muhtemel hataların farkında olduklarını göstermekte ve öğretmenlerin çoğunun temel bilgi eksiklerinin olduğuna işaret etmektedir. Baki (1998) tarafindan yapılan araştırmada da, ögrrencilerin cebirsel işlemlere yönelik yapabilecekleri hataları tahmin etmede kıdemli öğretmenlerin kıdemsiz öğretmenlere göre daha fazla neden gösterdikleri belirlenmiştir. Yine, Ardahan ve Ersoy (1998) tarafından yapılan bir çalışmada da, öğretmenlerin yanılgılarının, öğrenci yanılgılarını önemli ölçüde etkilediği tespit edilmiştir. $\mathrm{Bu}$ noktada araştırmacılara bu kavramsal eksikliği gidermeye yönelik deneysel çalışmalar yapmaları önerilmektedir.

\section{Kaynakça}

Akgün, L., Çiltaş, A., Deniz, D., Çiftçi, Z. ve Işık, A. (2013). İlköğretim matematik öğretmenlerinin matematiksel modelleme ile ilgili farkındalıkları. Adryaman Üniversitesi Sosyal Bilimler Enstitüsü Dergisi, 12, 1-34.

Akkuşci, Y. E. (2019). Matematik öğretiminde hata temelli aktivite uygulamalarının sınıf içi kullanımının etkililiğinin incelenmesi. (Yayımlanmamış yüksek lisans tezi). Atatürk Üniversitesi, Erzurum.

Akpınar B. ve Akdoğan, S. (2010). Negatif bilgi kavramı: Hata ve başarısızlıklardan öğrenme. Batı Anadolu Eğitim Bilimleri Dergisi, 1(1), 14-22.

Alacac1, C. (2015). Öğrencilerin kesirler konusundaki kavram yanılgıları. E. Bingölbali ve M. F. Özmantar (Ed.), Illköğretimde karşılaşılan matematiksel zorluklar ve çözüm önerileri içinde (ss. 63-95). Ankara: Pegem Akademi Yayıncılık.
Amaç, R. ve Didiş-Kabar, M. G. (2019). Matematik öğretmeni adaylarının cebirde harflerin kullanımı ve cebirsel işlemler ile ilgili öğrenci hatalarına yönelik farkındalıkları. Eğitimde Nitel Araştırmalar Dergisi, 7(4), 1525-1552. doi: 10.14689/issn.2148-2624.1.7c.4s.10m

Ardahan, H. ve Ersoy, Y. (1998). Yönlü say1larla ilgili sözel problemlerde olası yanılgılar ve öğretmenlerin tanıları. III. Ulusal Fen Bilimleri Ĕgitimi Sempozyumu. Karadeniz Teknik Üniversitesi, Trabzon, 23-25 Eylül, 50-55.

Arzarello, F., Ferrara, F., \& Robutti, O. (2012). Mathematical modelling with technology: The role of dynamic representations. Teaching Mathematics and Its Applications, 31, 20-30.

Baki, A. (1998). Cebirle ilgili işlem yanılgılarının değerlendirilmesi. III. Ulusal Fen Bilimleri Ĕ̆itimi Sетроzуити. Karadeniz Teknik Üniversitesi, Trabzon, 23-25 Eylül, 46-49.

Borasi, R. (1994). Capitalizing on errors as "springboards for inquiry": A teaching experiment. Journal for Research in Mathematics Education, 25(2), 166208.

Borasi, R. (1986). On the educational roles of mathematical errors: Beyond diagnosis and remediation. (Unpublished doctoral dissertation thesis). Dissertation, State University of New York, Bufalo.

Borasi, R. (1988). Towards a reconceptualization of the role of errors in education: The need for new metaphors. Annual Meeting of the American Educational Research Association, New Orleans, LA.

Borasi, R. (1989). Students' constructive uses of mathematical errors: A Taxonomy, Annual Meeting of the American Educational Research Association, San Francisco, 27-31 March, 1-36.

Borasi, R. (1996). Reconceiving mathematics instruction: A focus on errors. Norwood, NJ: Ablex Publishing Corporation.

Bostan-Işıksal, M. (2015). Negatif sayılara ilişkin zorluklar, kavram yanılgıları ve bu kavram yanılgıların giderilmesine yönelik öneriler. E. Bingölbali ve $\mathrm{M}$. F. Özmantar (Ed.)., İlkögretimde karşılaşılan matematiksel zorluklar ve çözüm önerileri içinde (ss. 155-186). Ankara: Pegem Akademi Yayıncilik.

Brenner, M. E., Mayer, R. E., Moseley, B., Brar, T., Duran, R., Reed, B., \& Webb, D. (1997). Learning by understanding: The role of multiple representations in learning algebra. American Educational Research Journal, 34(4), 663-689.

Bright, G. W., Behr, M. J., Post, T. R., \& Wachsmuth, I. (1988). Identifying fractions on number lines. Journal for Research in Mathematics Education, 19(3), 215-232. 
Çavuş-Erdem, Z. ve Gürbüz, R. (2018). Matematiksel modellemeye giriş. R. Gürbüz ve M. F. Doğan (Ed.)., Matematiksel modellemeye disiplinle arası bakış: Bir STEM yaklaşımı içinde (ss. 9-14). Ankara: Pegem Akademi Yayıncılık.

Çiltaş, A. (2011). Dizi ve seriler konusunun matematiksel modelleme yoluyla öğretiminin ilköğretim matematik öğretmeni adaylarının ögrenme ve modelleme becerileri üzerine etkisi (Yayınlanmamış Doktora Tezi). Atatürk Üniversitesi: Erzurum.

Dalehefte, I. M., Seidel, T., \& Prenzel, M. (2012). Reflecting on learning from errors in school instruction: Findings and suggestions from a swissgerman video study. In J. Bauer and C. Harteis (Eds). Human Fallibility: The Ambiguity of Errors for Work and Learning. Springer. Dordrecht.

Demirci, Ö., Özkaya, M. ve Konyalıoğlu, A. C. (2017). Öğretmen adaylarının olasılık konusuna ilişkin hata yaklaşımları. Erzincan Üniversitesi Eğitim Fakültesi Dergisi, 19(2), 153-172.

Durmaz, B. (2017). Matematik öğretmenleri ile adaylarının tamsayılarla dört işlemi sayma pullarıyla modelleme başarıları. KEFAD, 18(3), 171-192.

Eisner, E. W. (1997). Cognition and representation. Phi Delta Kapan, 78(5), 348-353.

Ekiz, D. (2009). Bilimsel araştırma yöntemleri (2. bask1). Ankara: Anı Yayıncılık.

English, L. D., \& Watters, J. (2004). Mathematical modelling with young children. 28th Conference of the International Group for the Psychology of Mathematics Education, 2, Bergen, 14-18 July, 335-342.

Gartmeier, M., Bauer, J., Gruber, H., \& Heid, H. (2008). Negative knowledge: Understanding professional learning and expertise. Vocations and Learn, 1, 87103.

Gedik, S. D. (2014). Matematik alan bilgisi geliştirme sürecine hata temelli aktivitelerin etkisi (Yayımlanmamış doktora tezi). Atatürk Üniversitesi: Erzurum.

Gedik, S. D. ve Konyalığlu, A. C. (2019). The influence of mistake-handling activities on mathematics education: An example of definitions. European Journal of Educational Research, 8(2), 467-476.

Ginat, D. (2003, February). The Greedy Trap And Learning From Mistakes, Proc of the $34^{\text {th }}$ ACM Computer Science Education Symposium - SIGCSE, Nevada, February, 11-15.

Heinze, A. (2005). Mistake-handling activities in German mathematics classroom. Proceedings of the $29^{\text {th }}$ Conference of the International Group for the Psychology of Mathematics Education, Melbourne University, Melbourne (Australien), 10-15 July, 105-112.

Ișık, A. ve Mercan E. (2015). Ortaokul matematik öğretmenlerinin model ve modelleme hakkındaki görüşlerinin incelenmesi. $K . \quad \ddot{U}$. Kastamonu Ĕ̆itim Dergisi, 23(4), 1835-1850.

Konyalığlu, A. C., Özkaya, M. ve Gedik, S. D. (2019). Ögretmen ve ögretmen adayları için matematik ögretiminde hata temelli aktiviteler. Erzurum: Ertual Akademi Yayıncilık.

Lehrer, R., \& Schauble, L. (2003). Origins and evaluation of model-based reasoning in mathematics and science. In R. Lesh \& H. M. Doerr (Eds.), Beyond constructivism: Models and modeling perspectives on mathematics problem solving, learning, and teaching 59-70. Mahwah, NJ: Lawrence Erlbaum.

Lesh, R., \& Doerr, H. M. (2003). Foundations of a models and modeling perspective on mathematics teaching, learning, and problem solving. In R. Lesh \& H. M. Doerr, (Eds.), Beyond constructivism: Models and modeling perspectives on mathematics problem solving, learning, and teaching, 3-33. Mahwah, NJ: Lawrence Erlbaum.

Lesh, R., Landau, M., \& Hamilton, E. (1983). Conceptual models in applied mathematical problem solving research. In R. Lesh \& M. Landau, (Eds.). Acquisition of mathematics concepts \& Processes, 263-343. New York.

Lesh, R., Post, T., \& Behr, M. (1987). Representations and translations among represetions in mathematics leraning and problem solving. In C. Janiver (Ed.), Problems of representations in the teaching and learning of mathematics, 33-40. Hillsdale, NJ: Lawrence Erlbaum.

Lingefjard, T. (2005). Model transitios in the real world: The Catwalk problem. Mathematical modelling: ICTMA 12: Education, engineering and economics. Horwood Publishing, Chichester, UK, 368-376.

Lowrie, T. (2001). The influence of visual representations on mathematical problem solving and numeracy performance. 24th Annual MERGA Conference, Sydney, July, 354-361.

Meyer, W. J. (1984). Concepts of mathematical modeling. New York: McGraw-Hill.

McMillan, J. H., \& Schumacher, S. (2010). Research in education, (seventy edition), Boston: Pearson Publishing.

National Council of Teachers of Mathematics [NCTM]. (2000). Principles and standards for school mathematics. Retrieved from http://www.nctm.org/Standards-and-

Positions/Principles-and-Standards on the 10th of July in 2019.

Özaltun, A., Hıdıroğlu, Ç., Kula, S. ve Bukova-Güzel, E. (2013). Matematik öğretmeni adaylarının modelleme sürecinde kullandıkları gösterim şekilleri. Turkish Journal of Computer and Mathematics Education, 4(2), 66-88.

Özkaya, M. (2015). Hata temelli aktivitelerin matematik ögretmenlerinin mesleki gelişimlerine etkisinin 
incelenmesi. (Yayımlanmamıș doktora tezi). Atatürk Üniversitesi: Erzurum.

Özkaya, M. ve Konyalığlu, A. C. (2019). Ortaokul matematik öğretmenlerinin konu alan bilgilerinin gelişiminde hata temelli aktiviteler: Kesirlerle toplama işlemi. Bayburt Ĕgitim Fakültesi Dergisi. 14(27), 23-52. doi: 10.35675/befdergi.475076

Özmantar, M. F., Bingölbali E. ve Akkoç, H. (2015). Matematiksel kavram yanılgıları ve çözüm önerileri. (4.baskı). Ankara: Pegem Akademi Yayıncılik.

Parviainen, J., \& Eriksson, M. (2006). Negative knowledge, expertise and organisations. International Journal of Management Concepts and Philosophy, 2(2), $140-153$

Pesen, C. (2008). Kesirlerin sayı doğrusu üzerindeki gösteriminde öğrencilerin öğrenme güçlükleri ve kavram yanılgıları. İönü Üniversitesi Eğitim Fakültesi Dergisi, 9(15), 157-168.

Radatz, H. (1979). Error analysis in mathematics education. Journal of Research in Mathematics Education, 10(3), 163-172.

Sağırlı, M. Ö. (2010). Türev konusunda matematiksel modelleme yönteminin ortaöğretim öğrencilerinin akademik başarllarl ve öz-düzenleme becerilerine etkisi. (Yayımlanmamış doktora tezi). Atatürk Üniversitesi: Erzurum.

Stickles, P. R. (2006). An analysis of secondary and middle school teachers' mathematical problem posing. (Unpublished doctoral thesis). Indiana University, Indiana.

Tversky, B. (2001). Spatial schemas in depictions. In M. Gattis, (Eds.). Spatial schemas and abstract thought, 79-111. Cambridge: MIT Press.

Wanjala, E. K., \& Orton, A. (1996). Teachers' knowledge of pupils' errors in algebra. Proceedings of the 20th Conference of the International Group for the Psychology of Mathematics Education., Valencia (Spain,), July 8-12, 411-418.
Yıldırım, A. ve Şimşek, H. (2013). Sosyal bilimlerde nitel araştırma yöntemleri (9. baskı). Ankara: Seçkin Yayıncilik.

Yin, R. (1994). Case study research. Design and methods. Thousand Oaks: SagePublications

\section{EK: Soru Formu}

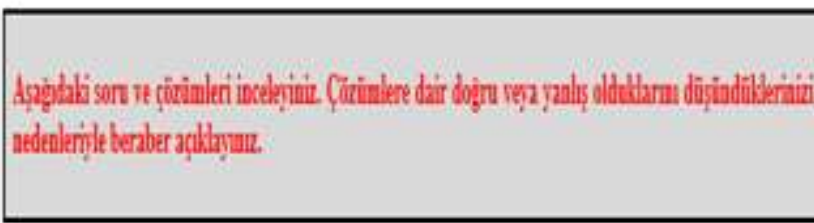

SORTLAR

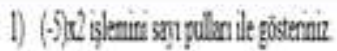

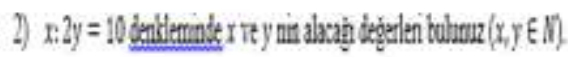

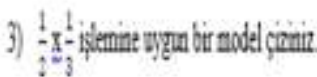

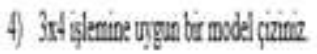

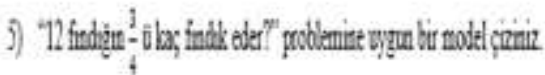

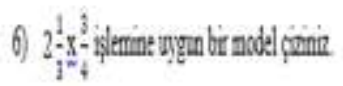

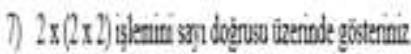

